\title{
PENGARUH KEPEMIMPINAN TERHADAP MOTIVASI KERJA KARYAWAN PADA PDAM KOTA MADIUN
}

\author{
Anum Reknowati Ningsih \\ Program Studi Pendidikan Ekonomi FPIPS IKIP PGRI MADIUN \\ anumretno_ekonomi55@yahoo.com
}

\begin{abstract}
This study aims to determine the leadership and employee motivation on the taps Madiun and to determine whether there is influence on employee motivation leadership at Madiun taps. Data collection using questionnaires, documentation, and observation. The analytical tool used in this study is simple linear regression analysis correlation test load, $\mathrm{f}$ test and t test using SPSS for windows 16.0. The results showed that the leadership have influence at the same time a positive relationship to employee motivation at PDAM Madiun. This means that the value of $f_{\text {hit }} \geq f_{\text {table }}(49.921 \geq 3.37$ or $\operatorname{Sig}_{\text {hit }} \leq \operatorname{Sig}_{\text {table }}(0,000 \leq 0.05)$, or it can be concluded reject $\mathrm{H}_{0}$, meaning no overall effect between leadership on employee motivation in PDAM Madiun. In addition, reliability test results obtained from the value of Cronbach's Alpha 0.859 and $0.944>0.70$. This means that the data collected is reliable (trustworthy).
\end{abstract}

Keywords: Leadership, Employee Motivation.

\begin{abstract}
Abstrak. Penelitian ini bertujuan untuk mengetahui kepemimpinan dan motivasi kerja karyawan pada PDAM Kota Madiun serta untuk mengetahui ada tidaknya pengaruh kepemimpinan terhadap motivasi kerja karyawan pada PDAM Kota Madiun. Penelitian ini merupakan penelitian deskriptif kuantitatif. Pengumpulan data menggunakan metode kuesioner, dokumentasi, danobservasi. Alat analisis yang digunakan dalam penelitian ini adalah analisis regresi linier sederhana memuat uji korelasi, uji $f$ dan uji $t$ dengan menggunakan bantuan program SPSS for windows 16.0. Hasil penelitian menunjukkan bahwa kepemimpinan mempunyai pengaruh sekaligus hubungan yang positif terhadap motivasi kerja karyawanpada PDAM Kota Madiun. Nilai $F_{\text {hitung }}$ adalah 49,912 sedangkan $\mathrm{F}_{\text {tabel }}$ sebesar 3,37, $\mathrm{Sig}_{\text {hitung }}$ adalah 0,000 sedangkan $\mathrm{Sig}_{\text {prob }} 0,05$. Hal ini berarti bahwa nilai $F_{\text {hitung }} \geq F_{\text {tabel }}\left(49,921 \geq 3,37\right.$ atau $\operatorname{Sig}_{\text {hitung }} \leq \operatorname{Sig}_{\text {tabel }}(0,000 \leq 0,05)$, atau dapat disimpulkan tolak $\mathrm{H}_{0}$, artinya ada pengaruh secara keseluruhan antara kepemimpinan terhadap motivasi kerja karyawan pada PDAM Kota Madiun. Selain itu diperoleh hasil uji reliabilitas dari nilai Cronbach's Alpha 0,859 dan 0,944>0,70. Artinya bahwa data yang dikumpulkan reliabel (dapat dipercaya).
\end{abstract}

Kata Kunci: Kepemimpinan, Motivasi Kerja Karyawan. 


\section{PENDAHULUAN}

Badan Usaha Milik Daerah (BUMD) merupakan unit usaha milik pemerintah yang bertujuan untuk mengoptimalisasi potensi ekonomi di daerah, dalam upaya menggali dan mengembangkan sumber daya daerah, memberikan pelayanan masyarakat serta mendorong pertumbuhan ekonomi daerah.Dalam sebuah organisasi atau perusahaan, sumber daya manusia mempunyai peranan yang penting untuk menjalankan suatu organisasi atau perusahaan. SDM sebagai penentu penggerak seluruh tujuan perusahaan. Manusia merupakan sumber daya yang berbeda dengan sumber daya yang lainnya, sebab manusia memiliki perasaan, keinginan dan hasrat. Oleh karena itu, SDM harus dikelola dan dibina dengan cermat agar mampun memberikan sumbangan yang optimal untuk perusahaan.

Werther, Davis 1996 (dalam Edy Sutrisno (2011:4), mengatakan bahwa sumber daya manusia adalah "pegawai yang siap, mampu dan siaga dalam mencapai tujuan-tujuan organisasi”. Dalam mencapai tujuan-tujuan organisasi atau perusahaan dibutuhkan seorang pemimpin. Menggerakkan SDM dalam perusahaan secara efektif tergantung pada cara-cara bagaimana pimpinan bertindak dalam memimpin perusahaan tersebut.

Pemimpin mempunyai tugas
penting dalam mengelola SDM,
pemimpin harus menyadari bahwa
karyawan merupakan asset yang paling
banyak mempengaruhi produktivitas
perusahaan. Selain menuntut karyawan
untuk bekerja secara optimal agar
mencapai tujuan perusahaan, disisi lain
perusahaan harus mengerti kebutuhan

karyawan. Pemimpin yang baik akan dapat memberikan motivasi yang positif terhadap karyawan.

Menurut Hasibuan (2007:92)
mengemukakan bahwa "motivas
mempersoalkan bagaimana cara
mendorong gairah kerja bawahan, agar mereka mau bekerja keras dengan memberikan semua kemampuan dan ketrampilannya untuk mewujudkan tujuan perusahaan". Motivasi kerja adalah melakukan pekerjaan secara giat, sehingga diharapkan pekerjaan akan cepat selesai dan hasilnya lebih baik. Dengan adanya motivasi maka perhatian, pemikiran, tenaga dan kegiatan karyawan dapat diarahkan untuk tujuan dan sasaran yang bermanfaat serta menguntungkan bagi perusahaan maupun bagi karyawan itu sendiri. Untuk mendorong karyawan agar dapat berprestasi maka setiap karyawan harus memiliki motivasi dan nilai etos yang tinggi terhadap perusahaan.

Salah satu faktor yang bisa mempengaruhi motivasi kerja karyawan yaitu kepemimpinan seorang pemimpin. Dalam sebuah organisasi atau perusahaan sifat dan sikap kepemimpinan seorang pemimpin untuk mempengaruhi orang lain sangat menentukan didalam mencapai tujuan organisasi atau perusahaan. Faktor kepemimpinan memegang peranan yang penting karena pemimpin itulah yang akan menggerakkan dan mengarahkan organisasi dalam mencapai tujuan dan sekaligus merupakan tugas yang tidak mudah. Pemimpin harus memahami setiap perilaku bawahannya yang berbedabeda. 
Anoraga (dalam Edy Sutrisno, 2011: 214), mengemukakan bahwa "kepemimpinan adalah kemampuan untuk mempenggaruhi pihak lain, melalui komunikasi baik langsung maupun tidak langsung dengan maksud untuk menggerakkan orang-orang agar dengan pengertian, kesadaran dan senang hati bersedia mengikuti kehendak pimpinan".Secara luas meliputi proses mempengaruhi dalam menentukan tujuan organisasi, memotivasi perilaku pengikut untuk mencapai tujuan, mempengaruhi untuk memperbaiki kelompok. Selain itu juga mempengaruhi interpretasi mengenai peristiwa-peristiwa para pengikutnya, pengorganisasian dan aktivitasaktivitas untuk mencapai sasaran, memelihara hubungan kerja sama dan kerja kelompok, perolehan kerja sama dari orang-orang diluar organisasi atau perusahaan. Seperti yang dikemukakan oleh Sudarwan Danim (2004:18), "kepemimpinan adalah faktor manusiawi yang mengikat suatu kelompok-kelompok bersama dan memberikannya motivasi menuju tujuan-tujuan tertentu, baik dalam jangka pendek maupun jangka panjang. Ini berarti antara kepemimpinan dan motivasi memiliki ikatan yang kuat".

Perusahaan Daerah Air Minum (PDAM) merupakan salah satu perusahaan yang dikelola oleh daerah atau usaha milik daerah. Dimana perusahaan ini dibentuk oleh Pemda yang bergerak di dibidang pengadaan, pengelolaan dan pengembangan air bersih. PDAM diharapkan dapat berfungsi sebagai pelayanan publik atau masyarakat disetiap kabupaten atau kota. PDAM sebagai perusahaan daerah diberi tanggung jawab untuk mengembangkan dan mengelola sistem penyediaan air bersih serta melayani semua kelompok konsumen dengan harga yang terjangkau. Di daerah Madiun terdapat Perusahaan Daerah Air Minum Tirta Taman Sari yaitu di Jln. Sulawesi No. 18. PDAM kota Madiun mempunyai visi dan misi dalam memberikan pelayanan yang terbaik bagi pelanggan dan masyarakat serta meningkatkan kesejahteraan pegawai dan meningkatkan kualitas SDM. PDAM kota Madiun mempunyai karyawan yang cukup banyak dan pelayanan yang ramah baik serta datadata yang dibutuhkan dalam penelitian ini tersedia menjadi salah satu alasan untuk melakukan penelitian di PDAM kota Madiun.

Berdasarkan uraian diatas, maka peneliti terdorong untuk mengangkat topik penelitian dengan judul "Pengaruh Kepemimpinan Terhadap Motivasi Kerja Karyawan Pada PDAM Kota Madiun".

Berdasarkan uraian diatas,
adapun rumusan masalah sebagai
berikut: Bagaimana kepemimpinan
pada PDAM kota Madiun, bagaimana
motivasi kerja karyawan pada PDAM
kota Madiun dan adakah pengaruh
kepemimpinan terhadap motivasi kerja
karyawan pada PDAM kota Madiun.

Schermerhom (dalam Winardi, 2001: 2) berpendapat "motivasi untuk bekerja, merupakan sebuah istilah yang digunakan dalam bidang perilaku keorganisasian, guna menerangkan kekuatan-kekuatan yang terdapat pada diri seseorang individu, yang menjadi penyebab timbulnya tingkat, arah dan persistensi yang dilaksanakan dalam hal bekerja". Motivasi kerja merupakan suatu kondisi yang menggerakkan seseorang untuk 
melakukan upaya yang maksimal dalam mencapai tujuan organisasi atau perusahaan yang didorong oleh kebutuhan-kebutuhan individu. Motivasi kerja karyawan adalah salah satu faktor penentu keberhasilan dari tujuan-tujuan yang telah ditetapkan perusahaan. Salah satu yang dapat mempengaruhi motivasi kerja karyawan yaitu kepemimpinan.

Siagian (dalam Edy Sutrisno, 2011: 213-214) berpendapat "kepemimpinan adalah kemampuan seseorang untuk mempengaruhi orang lain, dalam hal ini para bawahannya sedemikian rupa sehingga orang lain itu mau melakukan kehendak pimpinan meskipun secara pribadi hal itu tidak disenanginya". kepemimpinan merupakan proses mempengaruhi orang lain. Dengan kata lain, kepemimpinan difokuskan kepada apa yang dilakukan oleh para pemimpin, yaitu proses dimana pemimpin menjelaskan tujuan organisasi atau perusahaan kepada orang yang dipimpinnya (bawahan) serta memotivasi mereka untuk mencapai tujuan yang diinginkan. Sudarwan Danim, (2004: 18) "Kepemimpinan adalah faktor manusiawi yang mengikat suatu kelompok-kelompok bersama dan memberikannya motivasi menuju tujuan-tujuan tertentu, baik dalam jangka pendek maupun jangka panjang. Ini berarti antara kepemimpinan dan motivasi memiliki ikatan yang kuat".Dengan demikian maka dapat disimpulkan bahwa kepemimpinan akan mempengaruhi motivasi kerja karyawan, dengan kepemimpinan yang baik akan semakin memacu karyawan untuk bekerja lebih giat lagi.

\section{METODE PENELITIAN}

Lokasi penelitian dilaksanakan di PDAM kota Madiun, dengan mempertimbangkan penelitian tersebut belum pernah ada yaitu tentang pengaruh kepemimpinan terhadap motivasi kerja karyawan PDAM kota Madiun, letak objek penelitian tidak terlalu jauh sehingga diperoleh efektifitas dan efisiensi baik waktu, tenaga, maupun biaya. Waktu penelitian dilaksanakan pada bulan Pebruari-Juli 2015.

Metode penelitian yang digunakan adalah deskriptif kuantitatif. Adapun yang dimaksud deskriptif kuantitatif Menurut Sugiyono (2014: 13) metode kuantitatif dinamakan metode tradisional, karena metode ini sudah cukup lama digunakan sehingga sudah mentradisi sebagai metode untuk penelitian. Metode ini disebut sebagai metode positivstik karena berlandaskan pada filsafat positivisme. Metode ini sebagai metode ilmiah/scientific karena telah memenuhi kaidah-kaidah ilmiah yaitu konkrit/empiris, objektif, terukur, rasional, dan sistematis. Metode ini disebut metode kuantitatif karena data penelitian berupa angka-angka dan analisis menggunakan statistik. Sedangkan penelitian deskriptif, menurut Hamid Darmadi (2011: 7) adalah pengumpulan data untuk memberikan gambaran atau penegasan suatu konsep atau gejala, juga menjawab pertanyaan-pertanyaan sehubungan dengan suatu objek penelitian pada saat ini.

Penelitian ini mempunyai 2 variabel yaitu variabel bebas untuk kepemimpinan dan variabel terikat untuk motivasi kerja karyawan.. 
Agar lebih jelasnya dapat mengetahui tentang variabel dilihat pada gambar berikut ini : $\quad$ kepemimpinan dan variabel motivasi

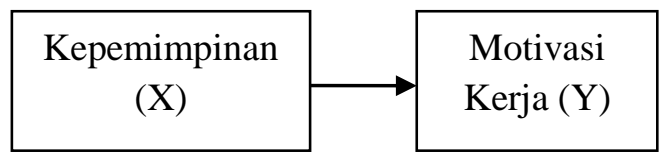

Definisi Operasional

\section{Variabel Bebas (independent)}

Menurut Sugiyono (2001: 33) "variabel bebas adalah variabel yang mempengaruhi atau yang menjadi sebab perubahannya atau timbulnya variabel dependen (terikat)". Variabel bebas dalam penelitian ini adalah kepemimpinan.

\section{Variabel terikat (dependent)}

Sugiyono (2001: berpendapat "variabel terikat adalah variabel yang dipengaruhi atau yang menjadi akibat, karena adanya variabel bebas". Variabel terikat dalam penelitan ini adalah motivasi kerja karyawan.

\section{Populasi, Sampel, Teknik Pengambilan Sampel}

Populasi penelitian ini adalah semua karyawan PDAM kota Madiun sebanyak 142 orang. Sampel Dalam penelitian ini sampel yang digunakan sebanyak 20\% dari jumlah populasi, cara yang digunakan untuk mengambil sampel menggunakan teknik Simple Random Sampling yaitu pengambilan sampel anggota populasi dilakukan secara acak tanpa memperhatikan strata yang ada dalam populasi. (Sugiyono, 2001: 74).

Teknik pengumpulan data yang digunakan dalam peneitian ini yaitu kuesionerberupa pertanyaanpertanyaan yang akan diberikan kepada karyawan PDAM Kota Madiun untuk
kerja.Melalui pemberian angket ini peneliti akan mendapatkan data yang obyektif dari responden untuk mengetahui seberapa besar pengaruh kepemimpinan terhadap motivasi kerja karyawan. Dokumentasi Menurut Arikunto (2002: 206) "dokumentasi adalah mencari data mengenai hal-hal atau variabel yang berupa catatan, transkrip, buku, surat kabar, majalah, prasasti, notulen rapat, lengger, agenda dan sebagainya".Observasi menurut Rianse, Abdi (2012: 213) berpendapat "observasi atau pengamatan adalah alat pengumpul data yang dilakukan dengan cara mengamati dan mencatat secara sistematik gejala-gejala yang diselidiki".Skala likert digunakan untuk mengukur sikap, pendapat, dan persepsi seseorang atau sekelompok orang tentang fenomena sosial. Dalam penelitian, fenomena sosial ini telah ditetapkan secara spesifik oleh peneliti, yang selanjutnya disebut sebagai variabel penelitian.

\section{HASIL PENELITIAN \\ 1. Deskripsi Variabel Motivasi Kerja \\ Deskripsi variabel} kepemimpinan dengan jumlah data sebanyak 28 orang memiliki deskripsi data sebagai berikut : a) Nilai rata-rata hitung (mean) 45,39, b) Median 47,00, c) Modus 47, d) Nilai Minimum 34, f) Nilai Maximum 50.

Berdasarkan nilai diatas yang mendapat nilai diatas rata-rata $\geq$ 45,39 sebanyak $75 \%$ (21 orang) sedangkan yang mendapat nilai dibawah rata-rata $\leq 45,39$ sebanyak $25 \%$ (7 orang). Artinya 
$75 \%$ (21 orang) setuju bahwa kepemimpinan dapat mempengaruhi motivasi kerja karyawan. Sedangkan $25 \% \quad(7$ orang) tidak setuju bahwa kepemimpinan dapat mempengarui motivasi kerja karyawan.

\section{Deskripsi}

Variabel

\section{Kepemimpinan}

Deskripsi, variabel motivasi kerja karyawan dengan jumlah data sebanyak 28 orang memiliki deskripsi data sebagai berikut: a) Nilai rata-rata hitung (mean) 90,00, Median 93,50, c) Modus 95, d) Standar Deviasi 7,216, e) Nilai Minimum 75 f) Nilai Maksimum 99.

Berdasarkan nilai diatas yang mendapat nilai diatas rata-rata $\geq$ 90,00 sebanyak $71,43 \%$ (20 orang) dan yang mendapat nilai dibawah rata-rata $\leq 90,00$ sebanyak $28,6 \%$ (8 orang). Artinya $71,43 \% \quad(20$ orang) setuju bahwa motivasi kerja karyawan dipengaruhi oleh kepemimpinan sedangkan 28,6\% (8 orang) tidak setuju bahwa motivasi kerja karyawan dipengaruhi oleh kepemimpinan.

\section{Pengujian Hipotesis}

Pengujian hipotesis dalam penelitian adalah untuk mencari pengaruh kepemimpinan terhadap motivasi kerja karyawan pada PDAM kota Madiun.

Untuk uji hipotesis tidak digunakan perhitungan secara manual, akan tetapi digunakan alat bantu SPSS fof windows 16.0 yang diperoleh hasil sebagai berikut:

\section{Uji Korelasi}

Uji korelasi digunakan untuk mencari keeratan hubungan antara Kepemimpinan terhadap Motivasi Kerja Karyawan.

a. Hipotesis

Hipotesis yang digunakan dalam uji korelasi adalah sebagai berikut:

1) Tolak $\mathrm{H}_{0}$, apabila $\mathrm{r}_{\text {hit }} \geq \mathrm{r}_{\text {tab }}$ berarti ada hubungan yang signifikan antara kepemimpinan terhadap motivasi kerja karyawan pada PDAM kota Madiun.

2) Terima $\mathrm{H}_{0}$, apabila $r_{\text {hit }} \leq r_{\text {tabel }}$ berarti tidak ada hubungan yang signifikan antara kepemimpinan terhadap motivasi kerja karyawan pada PDAM Kota Madiun.

b. Hasil Analisis Data

Dari perhitungan SPSS dapat diketahui bahwa nilai $r_{\text {hitung }}$ adalah 0,811 sedangkan $r_{\text {tabel }} \quad 0,374$. Ini berarti bahwa nilai $r_{\text {hitung }} \geq r_{\text {tabel }}$ $(0,811 \geq 0,374)$, atau dapat disimpulkan tolak $\mathrm{H}_{0}$, artinya ada hubungan yang signifikan antara kepemimpinan dan motivasi kerja karyawan pada PDAM Kota madiun.

Dilain pihak apabila dilihat dari determinasi atau sumbangan kepemimpinan terhadap motivasi kerja karyawan dapat dilihat dari besarnya nilai $\mathrm{R}^{2}$ ( $\mathrm{R}$ Square) adalah 0,657. Jadi sumbangan pengaruh dari kepemimpinan terhadap motivasi kerja karyawan yaitu $65,7 \%$ sedangkan sisanya sebesar 34,3\% dipengaruhi oleh faktor lain. 


\section{Uji f/Uji Fisher}

Uji f digunakan untuk menguji pengaruh kepemimpinan terhadap motivasi kerja karyawan.

a. Hipotesis

Hipotesis yang digunakan dalam uji f adalah sebagai berikut:

1) Tolak $\mathrm{H}_{0}$, apabila $\mathrm{Sig}_{\text {hitung }} \leq$ Sig $_{\text {prob }}$ atau $F_{\text {hit }} \geq F_{\text {tabel }}$ berarti ada pengaruh secara keseluruhan antara kepemimpinan terhadap motivasi kerja karawan pada PDAM Kota Madiun.

2) Terima $\mathrm{H}_{0}$, apabila Sig $_{\text {hitung }} \geq$ Sig $_{\text {prob }}$ atau $F_{\text {hit }} \leq \mathrm{F}_{\text {tabel }}$ berarti tidak ada pengaruh secara keseluruhan antara kepemimpinan terhadap motivasi kerja karyawan pada PDAM Kota Madiun.

b. Hasil Analisis Data

Dari hasil uji Anova dapat diketahui bahwa nilai $F_{\text {hitung }}$ adalah 49,912 sedangkan $F_{\text {tabel }}$ sebesar 3,37, Sig $_{\text {hitung }}$ adalah 0,000 sedangkan $\mathrm{Sig}_{\text {pro }}$ 0,05. Ini berarti bahwa nilai $F_{\text {hitung }} \geq F_{\text {tabel }}(49,921$ $\geq 3,37$ atau Sig $_{\text {hitung }} \leq \operatorname{Sig}_{\text {tabel }}$ $(0,000 \leq 0,05)$, atau dapat disimpulkan tolak $\mathrm{H}_{0}$, artinya ada pengaruh secara keseluruhan antara kepemimpinan terhadap motivasi kerja karyawan pada PDAM Kota Madiun.

\section{Uji t/Uji Beda}

Uji t digunakan untuk mencari beda pengaruh antara kepemimpinan terhadap motivasi kerja karyawan.

a. Hipotesis

Hipotesis yang digunakan dalam uji t adalah sebagai berikut:

1) Tolak $\mathrm{H}_{0}$ apabila $\operatorname{Sig}_{\text {hit }} \leq$ $\operatorname{Sig}_{\text {prob }}$ atau $\mathrm{t}_{\text {hit }} \geq \mathrm{t}_{\text {tabel }}$ berarti ada beda pengaruh antara variabel X dan variabel Y.
2) Terima $\mathrm{H}_{0}$ apabila Sighit $_{\text {hit }} \geq$ Sig prob $_{\text {atau }} t_{\text {hit }} \leq t_{\text {tabel }}$ berarti tidak ada beda pengaruh antara variabel $\mathrm{X}$ dan variabel Y.

b. Hasil Analisis Data

Dari perhitungan SPSS diperoleh hasil persamaan Garis Regresi dinyatakan dengan $\mathrm{Y}=$ $8,201+1,802 \mathrm{X}$ artinya adalah apabila kepemimpinan ditingkatkan $1 \%$ maka motivasi kerja karyawan akan naik 1,802\% apabila faktor lain konstan/ tetap. Hasil uji t dapat diketahui bahwa $\mathrm{t}_{\text {hitung }}$ adalah 7,065 $\mathrm{t}_{\text {tabel }} 1,706$, sig $_{\text {hit }}$ adalah 0,000 sedangkan $\mathrm{Sig}_{\text {pro }}$ 0,05 . Hal ini berarti bahwa nilai $t_{\text {hitung }} \geq t_{\text {tabel }}(7,065 \geq 1,706)$ atau $\operatorname{Sig}_{\text {hit }} \leq \operatorname{Sig}_{\text {prob }}(0,000 \leq 0,05)$, atau dapat disimpulkan tolak $\mathrm{H}_{0}$, artinya ada beda pengaruh antara kepemimpinan terhadap motivasi kerja karyawan pada PDAM Kota Madiun.

\section{Simpulan Hasil Analisis}

Dari hasil analisis data yang telah dilakukan dapat diambil simpulan sebagai berikut:

a. Simpulan Uji Korelasi

Dalam uji korelasi diperoleh nilai besarnya nilai $r_{\text {hitung }}$ adalah 0,811 sedangkan $r_{\text {tabel }} 0,374$. Hal ini berarti bahwa nilai $r_{\text {hitung }} \geq r_{\text {tabel }}$ $(0,811 \geq 0,374)$, atau dapat disimpulkan tolak $\mathrm{H}_{0}$, artinya ada hubungan yang signifikan antara kepemimpinan dan motivasi kerja karyawan pada PDAM Kota Madiun.

Dilain pihak apabila dilihat dari determinasi atau sumbangan kepemimpinan terhadap motivasi kerja karyawan dapat dilihat dari besarnya nilai $\mathrm{R}^{2}$ ( $\mathrm{R}$ Square) 
adalah 0,657. Jadi sumbangan pengaruh dari kepemimpinan terhadap motivasi kerja karyawan yaitu $65,7 \%$ sedangkan sisanya sebesar 34,3\% dipengaruhi oleh faktor lain.

b. Simpulan Uji Fisher

Dari hasil analisis data yang telah dilakukan untuk uji Fisher diperoleh hasil bahwa nilai $F_{\text {hitung }}$ sebesar 49,912 sedangkan $F_{\text {tabel }}$ 3,37 . Hal ini berarti nilai $F_{\text {hitung }}>$ $\mathrm{F}_{\text {tabel }}(49,912>3,37)$. Artinya ada pengaruh antara kepemimpinan terhadap motivasi kerja karyawan pada PDAM Kota Madiun.

c. Simpulan Uji t

Dari hasil analisis yang digunakan dalam uji $\mathrm{t}$ diperoleh persamaan garis regresi dinyatakan dengan $Y=8,201+1,802 X$ artinya adalah apabila kepemimpinan ditingkatkan $1 \%$ maka motivasi kerja karyawan akan naik 1,802\% apabila faktor lain konstan/ tetap.

Hasil uji t dapat diketahui bahwa $t_{\text {hitung }}$ adalah $7,065 \mathrm{t}_{\text {tabel }}$ 1,706, sig $_{\text {hit }}$ adalah 0,000 sedangkan $\mathrm{Sig}_{\text {pro }} 0,05$. Hal ini berarti bahwa nilai $t_{\text {hitung }} \geq \mathrm{t}_{\text {tabel }}$ $(7,065 \geq 1,706)$ atau $\operatorname{Sig}_{\text {hit }} \leq \operatorname{Sig}_{\text {prob }}$ $(0,000 \leq 0,05)$, atau dapat disimpulkan tolak $\mathrm{H}_{0}$, artinya ada beda pengaruh antara kepemimpinan terhadap motivasi kerja karyawan pada PDAM Kota Madiun.

\section{PENUTUP}

\section{Simpulan}

Dari penelitian yang berjudul “ pengaruh Kepemimpinan Terhadap Motivasi Kerja Karyawan pada PDAM Kota Madiun" dapat disimpulkan sebagai berikut:
1. Kepemimpinan pada PDAM Kota Madiun dikatakan sudah baik. Hal tersebut dapat dilihat dari hasil analisis statistik deskriptif dengan hasil yang diperoleh sebanyak $75 \%$ (21 orang) setuju bahwa kepemimpinan dapat mempengaruhi motivasi kerja karyawan. Sedangkan sebanyak $25 \%$ (7 orang) tidak setuju bahwa kepemimpinan dapat mempengarui motivasi kerja karyawan.

2. Motivasi Kerja Karyawan pada PDAM Kota Madiun juga dikatakan sudah baik. Hal tersebut dapat dilihat dari hasil analisis statistic deskriptif dengan hasil yang diperoleh sebanyak $71,43 \%$ (20 orang) setuju bahwa motivasi kerja karyawan dipengaruhi oleh kepemimpinan sedangkan $28,6 \%$ (8 orang) tidak setuju bahwa motivasi kerja karyawan dipengaruhi oleh kepemimpinan.

3. Kepemimpinan mempunyai pengaruh terhadap Motivasi Kerja Karyawan pada PDAM Kota Madiun. Terbukti dari hasil analisis regresi yaitu $\mathrm{Y}=8,201+$ $1.802 \mathrm{X}$. Artinya ada pengaruh antara kepemimpinan terhadap motivasi kerja karyawan pada PDAM Kota Madiun. Dari hasil Uji r, Uji F, dan Uji t diperoleh hasil sebagai berikut:

a. Uji Korelasi, yaitu $\mathrm{r}_{\text {hitung }}$ sebesar 0,811 sedangkan $r_{\text {tabel }}$ 0,374 . Hal ini berarti nilai $r_{\text {hitung }}>r_{\text {tabel }}(0,811>0,374)$. Artinya ada hubungan kepemimpinan terhadap motivasi kerja karyawan pada PDAM Kota Madiun. Sedangkan determinasi atau sumbangan sebesar 0,657 atau sebesar $65,7 \%$. 
b. Uji F, yaitu $F_{\text {hitung }}$ sebesar 49,912 sedangkan $F_{\text {tabel }} 3,37$. Hal ini berarti nilai $F_{\text {hitung }}>$ $\mathrm{F}_{\text {tabel }}(49,912>3,37)$. Artinya ada pengaruh antara kepemimpinan terhadap motivasi kerja karyawan pada PDAM Kota Madiun.

c. Uji t, yaitu $t_{\text {hitung }} 7,065$ sedangkan $t_{\text {tabel }} 1,706$. Hal ini berarti nilai $t_{\text {hitung }}>t_{\text {tabel }}(7,065$ $>1,706$ ). Dari perhitungan uji $\mathrm{t}$ diperoleh persamaan regresi sebagai berikut $\mathrm{Y}=8,201+$ $1,802 X$. Artinya ada beda pengaruh antara kepemimpinan terhadap motivasi kerja karyawan pada PDAM Kota Madiun.

\section{Saran}

1. Bagi pemimpin

a. Perlu adanya peningkatan motivasi kerja karyawan dengan cara memberikan pujian dan semangat kepada karyawan atas apa yang telah dikontribusikan untuk perusahaan.

b. Perlu peningkatan komunikasi dengan karyawan sehingga dapat terjalin hubungan yang baik dan tujuan perusahaan dapat tercapai.

2. Bagi karyawan

a. Perlu adanya peningkatan motivasi kerja dengan baik agar dalam pekerjaan dapat memberikan hasil yang memuaskan dengan cara melaksanakan pekerjaan dengan sungguh-sungguh apa yang telah dibebankan kepadanya.

b. Karyawan mampu mempertahankan bahkan meningkatkan kualitas kerja agar tujuan perusahaan dapat tercapai.

3. Bagi PDAM Kota Madiun

a. Meningkatkan motivasi kerja karyawan, baik motivasi yang bersifat finansial maupun non finansial.

b. Memberikan rasa aman bagi karyawan dengan pemberian JAMSOSTEK.

4. Bagi Peneliti Selanjutnya

'Bagi peneliti selanjutnya, sebaiknya mengembangkan penelitian dengan menggunakan variabel bebas lain selain kepemimpinan, karena selain kepemimpinan masih banyak faktor lain yang mempengaruhi motivasi kerja karyawan.

\section{DAFTAR PUSTAKA}

Amin Silalahi, Gabriel. 2003. Metodologi Penelitian dan Studi Kasus. Sidoarjo: CV. Citra Media

Arikunto, Suharsimi. 2002. Prosedur Penelitian Suatu Pendekatan Praktek Edisi Revisi V. Jakarta: Rineka Cipta.

2010. Predur Penelitian Suatu Pendekatan Praktik. Jakarta: Rineka Cipta

Danim, Sudarwan. 2004. Motivasi Kepemimpinan dan Efektivitas Kelompok. Jakarta: PT. Asdi Mahasatya.

Darmadi, Hamid. 2011. Metodologi Penelitian Pendidikan. Bandung: Alfabeta. 
Fahmi, Irham. 2013. Manajemen Kepemimpinan. Bandung: Alfabeta.

Gomes, Faustino, Cardoso. 2003. Manajemen Sumber Daya Manusia. Yogyakarta: Andi Offset.

Hasibuan, Malayu. 2007. Organisasi dan Motivasi. Jakarta: PT. Bumi Aksara.

Noor, Juliansyah. 2011. Metodologi Penelitian. Jakarta: Kencana Prenada Media Group.

Rianse dan Abdi. 2012. Metodologi Sosial dan Ekonomi. Bandung: Alfabeta.

Rivai dan Mulyadi. 2003. Kepemimpinan dan Perilaku Organisasi. Jakarta: PT. Rajagrafindo Persada.

Siregar, Syofian. 2014. Statistik Parametrik Untuk Penelitian Kuantitatif. Jakarta: PT. Bumi Aksara.

Sugiyono. 2001. Metodologi Penelitian Bisnis. Bandung: Alfabeta.

\section{- 2010. Metodologi Penelitian Pendidikan. Jakarta: Rineka Cipta}

Sugiyono. 2014. Metodologi Penelitian Pendidikan. Bandung: Alfabeta.

Sulistiyani dan Rosidah. 2003. Manajemen Sumber Daya Manusia. Yogyajakta: Graha Ilmu.
Sunyoto, Danang. 2013. Sumber Daya Manusia. Jakarta: PT. Buku Seru.

Saydam, Gauzali. 2005. Manajemen Sumber Daya Manusia. Jakarta: Djambatan.

Sutrisno, Edy. 2011. Manajemen Sumber Daya Manusia. Jakarta: Kencana Predana Media Group.

Winardi. 2001. Motivasi dan Pemotivasian Dalam Manajemen. Jakarta: PT. Rajagrafindo Persada.

Yulk, Gary. 2005. Kepemimpinan Dalam Organisasi. Jakarta: PT. Indeks 